\title{
Start-up tries bidding model to outsource academic research
}

Marc Lippman was facing a tight deadline. His grant application to the Susan G. Komen for the Cure foundation was due on 20 August of this year, and, with a week to go before the closing date, he still hadn't gathered all of the requisite preliminary data. "I just needed to have the information," recalls Lippman, chair of the department of medicine at the University of Miami Miller School of Medicine.

Fortunately, his former postdoc Elizabeth Iorns had just launched a new website called Science Exchange to help scientists outsource their research. Lippman posted that he needed someone to quickly analyze all the microRNAs involved in driving metastasis in breast cancer, and Emory University's Cancer Genomics Shared Resource agreed to take on the rushed job for just $\$ 7,000$. Lippman mailed off his tumor samples, and, within a week, he had all the raw data and bioinformatics analysis back from the Atlanta laboratory. To his relief, he managed to get his grant completed and submitted on time.

Although Lippman could have turned to a core facility at his own institution, "in this case, it was cheaper and a hell of a lot faster" to outsource the project, he says. "I haven't gotten data back this fast in my life, and they did a better analysis then I've ever seen. It was lovely."

The problem, according to Lippman and others, is that it's often hard to find an academic institution with the expertise and equipment to take on projects on short turnaround times. Over the past two years, the US National Center for Research Resources (NCRR) has funded efforts to remedy the situation, including a nine-institution, shared resource repository called the eagle-i Consortium, a network of Institutional Development Awards-funded core laboratories to coordinate facilities in small states with fewer investigators and resources, and a national social network of biomedical scientists called VIVO. The Association for Biomolecular Resource Facilities (ABRF), an international collective of more than 140 core labs, also maintains searchable 'white pages' and 'yellow pages' directories of people and facilities associated with the organization. But all of these efforts often struggle to stay up to date without continuous curation.

Enter Science Exchange. "Science Exchange may be able to have very fresh information as compared to what may be on an outdated website," says Gregory Farber, director of the Office of Technology Development and Coordination in the US National Institute of Mental Health. "It's all in front of me on one webpage, in one place," adds Megan Rieger, a

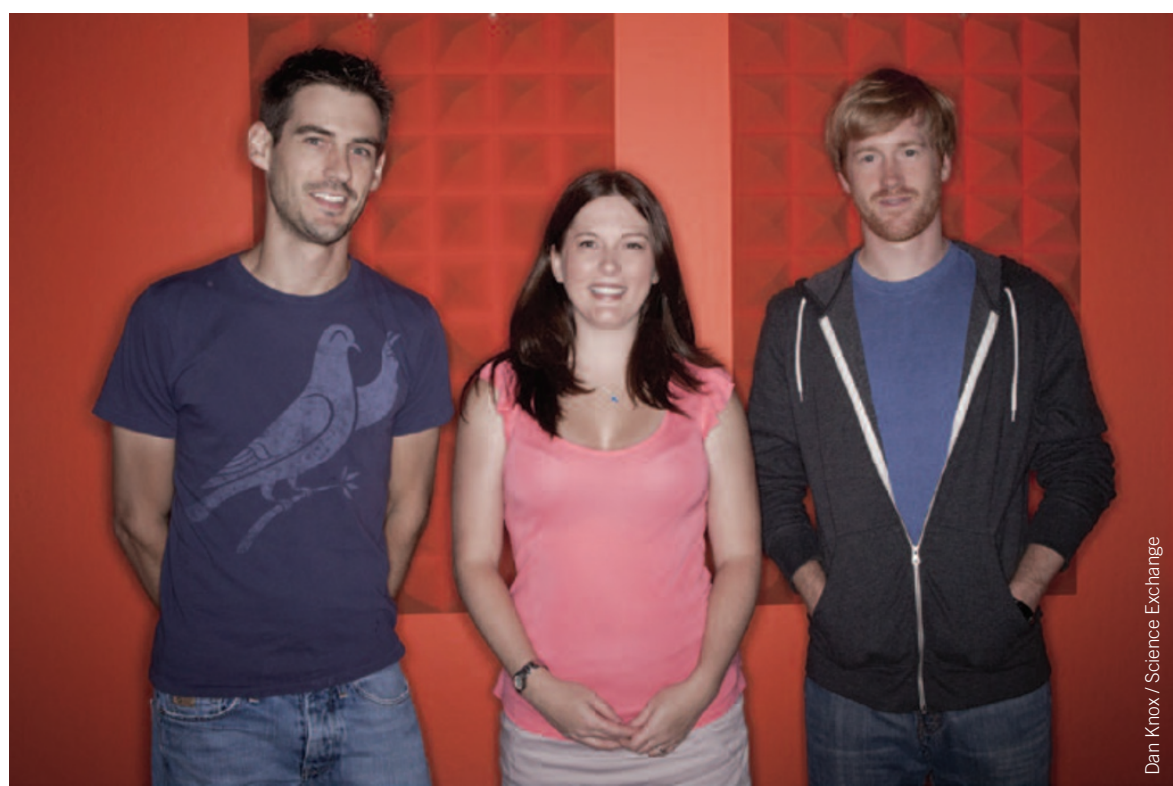

Exchanging ideas: Science Exchange founders Dan Knox (left), Elizabeth Iorns and Ryan Abbott.

postdoc and cancer researcher at the University of Southern California in Los Angeles who has used the new online marketplace to outsource some small histology projects. Plus, she adds, "I'm looking to save my lab some money, and here's an easy way to do it."

\section{Trusted provider}

Science Exchange launched in mid-August and already claims to count more than 2,700 scientist-users, and close to 200 institutions around the world that have registered as 'providers' capable of taking on jobs. Modeled after websites such as oDesk and Elance that help match freelancers with employers, the Palo Alto, California startup lets researchers post projects, and then registered providers can bid on contracts. The company makes money by charging a commission on completed jobs-roughly $5 \%$ for projects under $\$ 5,000$, and a sliding scale above that.

Iorns, a breast cancer biologist formerly at the University of Miami, cofounded the company together with web developer Ryan Abbott and business executive Dan Knox, with financial backing from Y Combinator, a Silicon Valley startup incubator program, and angel investors. She expects the platform to transform the landscape for academic research. For one thing, she says, it could free scientists from the convention of relying solely on external grants to fund their research. "You could envision a situation where as a young investigator I would choose to use my specialized skills to do experiments for other people one day a week," Iorns says. "That would mean that I wouldn't have to be applying for grants all the time."

"This will make the whole market for funding more liquid, so people will be using their specialization and equipment to the best market value," she adds.

For now, most of the providers are not individuals but nonprofit core facilities that are mostly looking to help cover their operating costs. "It's an opportunity for growth," says Deborah Berry, codirector of the histopathology and tissue shared resource at Georgetown University's Lombardi Cancer Center in Washington, DC, which has run a few experiments through Science Exchange. "Any project that I can get from an external source is bringing money and development into my facility."

ABRF President Anthony Yeung, a biochemist at the Fox Chase Cancer Center in Philadelphia who ran core facilities for more than 20 years, notes that Science Exchange will prove useful for some types of procedures, such as DNA sequencing, that can now be done "in an assembly-line manner." But he points out that for more complex tasks, the service won't be able to replicate the kind of planning, trial and error and response to feedback found with local core facilities or collaborators. "Science is more than buying of a product," Yeung says. "Our people know each other, and that makes or breaks the project. That is not something you can easily outsource."

Elie Dolgin 